\title{
Pediculated autologous vascularized pericardial flap aortoplasty for correction of simple aortic coarctation or associated with hypoplasia, atresia or interruption of aortic arch
}

\author{
Retalho de pericárdio pediculado vascularizado autógeno para aortoplastia e correção da coarctação \\ simples de aorta torácica, ou associada à hipoplasia, atresia ou interrupção do arco aórtico
}

Paulo RODRIGUES DA SILVA

RBCCV 44205-854

\section{Abstract}

Objective: Eighteen years ago, two young male patients of 8 months and 13 years with aortic coarctation associated to aortic hypoplasia between the left subclavian artery and the coarctated area, were submitted to surgical correction using a new world-pioneering surgical technique developed in our service.

Method: This technique consists of sectioning the patent ductus arteriosus, followed by resection of all the coarctated tissue in the aortic wall and aortoplasty correction by means of the lengthwise implantation of a pediculated autogenous pericardial flap. This flap is inserted into the thoracic aorta, from the root of the left subclavian artery to $2.0 \mathrm{~cm}$ below the coarctated area.

Results: For both patients, the blood pressure and arterial pulses of both arms and legs have been normal since the surgery until the present moment. Clinical examination and Doppler evaluation evidenced no pressure gradient between arms and legs, normal blood flow and no pressure gradient through the coarctated area. Both patients were submitted to other evaluations 18 years after surgery, including cardiac and thoracic aortic catheterization followed by aortography. These evaluations demonstrated normal aortic configuration, with normal diameter, including the areas above and below the coarctated site. There was no evidence of any kind of degenerative lesions of the vascularized pericardial flap or re-coarctation of the lesion and no signs of aneurysms forming or the presence of atherosclerosis of the flap. Moreover, and very importantly, it was evident that the pediculated completely vascularized autologous pericardial flap had been kept alive and had grown in diameter as well as in length.

Conclusion: The surgical technique using a pediculated vascularized autologous pericardial flap is the most complete and adequate for the correction of the different types of simple or complex forms of thoracic aortic coarctation in all age groups, including newborn babies when compared to all the existing techniques.

Descriptors: Aortography. Aorta, surgery.

Instituto de Cardiologia de Laranjeiras and Hospital da Ordem $3^{\text {a }}$ de S. Francisco da Penitência - Rio de Janeiro - Brazil 


\section{Resumo}

Objetivo: Dezoito anos atrás, dois jovens pacientes, do sexo masculino, com 8 meses e 13 anos de vida, ambos com coarctação da aorta torácica associada à hipoplasia da aorta, entre a artéria subclávia esquerda e a área coarctada, foram submetidos à correção cirúrgica destas lesões por meio de uma nova e pioneira técnica cirúrgica desenvolvida por nós.

Método: A técnica consiste na seç̧ão do canal arterial e ressecção de todo tecido coarctado da aorta, seguida por uma aortoplastia, utilizando-se de um retalho longitudinal de pericárdio vascularizado autógeno, implantado desde a saída da artéria subclávia até $2,0 \mathrm{~cm}$ abaixo da área coarctectomizada. Em ambos os casos, a pressão arterial sistêmica e os pulsos arteriais dos membros superiores e inferiores ficaram normais, imediatamente após a cirurgia até os dias de hoje.

Resultados: Os exames clínicos e de medidas com Doppler mostraram, respectivamente, nenhum gradiente pressórico braço/perna, assim como, demonstraram fluxo sanguíneo arterial normal e não gradiente arterial pressórico através da área coartectomizada. Ambos foram submetidos a rigorosas avaliações 18 anos após a cirurgia, incluindo cateterismo cardíaco e torácico aórtico, com aortografia, testes

\section{INTRODUCTION}

Aortic coarctation is, frequently, a congenital narrowing of the highest portion of the thoracic descending Aorta, near to the connection or insertion of the Patent Ductus Arteriosus (PDA).

Although the first successful correction of Aortic Coarctation (AoC) was performed more than sixty-one years in 1945 by Crafoord and Nylin [1], we still do not have an ideal surgical technique to correct these lesions in all their different forms and in all age groups, including newborn babies.

Several surgical techniques related to the correction of thoracic aortic coarctation in both its simple and aortic complex forms (Aortic hypoplasia, atresia or luminal interruption of Aortic Arch) have been published internationally [1-8].

All of them present surgical and technical limitations, and are not adequate to completely correct this pathology in all age groups, specifically in newborn babies.

Most of these surgical techniques, when applied to under one-year-old patients, have a high incidence of recoarctation in the postoperative period.

Some of them utilize synthetic or biological prosthetic ergométricos e angiotomografia computadorizada aórtica. Essas avaliações mostraram uma configuração aórtica normal, com diâmetros transversos normais, inclusive nas regiões acima e abaixo da área coartectomizada. Não houve demonstração de qualquer forma de lesão degenerativa do retalho pericárdico pediculado implantado ao longo dos anos, assim como nenhuma identificação de lesão aneurismática, de sinais de lesão aterosclerótica no mesmo, ou de recoarctação. Mais importante, é que ficou evidente que o retalho pericárdico pediculado totalmente vascularizado, assim utilizado, é mantido vivo, e cresceu ao longo dos anos, tanto em seu diâmetro como em seu comprimento.

Conclusão: A técnica do emprego do retalho pericárdico pediculado, vascularizado e autógeno é a mais adequada e a mais completa em comparação com todas as outras técnicas cirúrgicas existentes para correção dos diferentes tipos de coarctação da aorta torácica, nas suas formas simples ou associadas a outras lesões aórticas. É indicada em todas as faixas etárias, inclusive em recém-natos.

Descritores: Coartação aórtica, cirurgia. Aorta, cirurgia. Procedimentos cirúrgicos cardíacos.

materials often causing aneurysmatic lesions at the operated site [9].

Even though the Waldhausen surgical technique [4], using the proximal portion of the left subclavian artery as a flap to achieve an ideal aortoplasty, has proved to provide the best surgical results so far, there may be two very significant complications are associated to it:

a) Subclavian steal syndrome

b) A physical under-development of the left arm, which may become ischemic or gangrenous.

Faced with these problems, we developed a new surgical technique that is able to correct all the different forms of aorta coarctation and that might be considered an "ideal surgical technique”.

Some of the qualities of the technique are described as follows:

a) It is capable of completely overcoming obstructions with the complete resection of all the coarcted area.

b) It is capable of being used in all patients (including newborn babies).

c) It does not jeopardize any arterial branches including the left subclavian artery

d) No prosthetic materials, artificial or biological, are used only the patient's own tissue. 
e) It is capable of correcting all the usual associated thoracic aortic wall lesions.

f) The coarctomized area is capable of accompanying the normal growth potential in the postoperative period.

g) The present technique does not leave any type of circumferential suture line in the thoracic aortic wall ("purse string type").

h) It is possible to perform the technique with minimal surgical aortic dissection.

i) It is possible to correct long segments of stenosed aorta above the main coarcted lesion.

j) This technique has not shown so far, either immediate or long-term anatomic re-coarctation processes.

\section{METHOD}

\section{Surgical technique}

Based upon clinical, surgical and research experiences, we developed a new surgical technique, which we initially applied 18 years ago to two patients with $\mathrm{CoA}$ and thoracic aortic hypoplasia of the isthmus portion of the descending aorta, achieving total surgical and clinical success in the immediate and in long term periods.

The surgery consisted in a total resection of the coarcted area, followed by an Aortoplasty using a "pediculated vascularized autologous pericardial flap”.

1) The surgical technique was performed through left posterolateral thoracotomy, exposing the descending thoracic aorta from the origin of the left subclavian artery to $2.5 \mathrm{~cm}$ below the coarcted lesion.

2) Sectioning of the patent ductus arteriosus (PDA).

3) Excision of all ductal tissue extended to the aortic wall.

4) This excision must be extended $2 \mathrm{~cm}$ distally beyond the coarcted lesion. There are ductal tissues in the aortic wall that are not easily seen by the surgeon.

5) As previously mentioned, the lengthwise aortic incision must start at the anterior side of the left subclavian artery and continue 2 centimeters below the final transverse anastomosis of the proximal and distal aortic cuff.

The upper edge of this lengthwise aortic incision should terminate at the transverse incision, in a "T-shape".

6) The aortic diameter above and below the coarcted area must be measured, to calculated the correct width of the longitudinal autologous pericardial flap, and also to have the diameter of the proximal aortic cuff identical to the distal cuff.

7) The necessary length of the pediculated pericardial flap was measured in order to reach the longitudinal aortic incision without any tension.

8) The vascularized pediculated pericardial flap must be dissected from a region near to the left phrenic nerve in the pericardium sac, taking care to preserve the arterial branches which supply blood to the pericardium itself.

As is well known, the pericardium is highly vascularized by branches of the brachial, superior diaphragmatic, thymic and medial esophageal arteries (Figure 1).

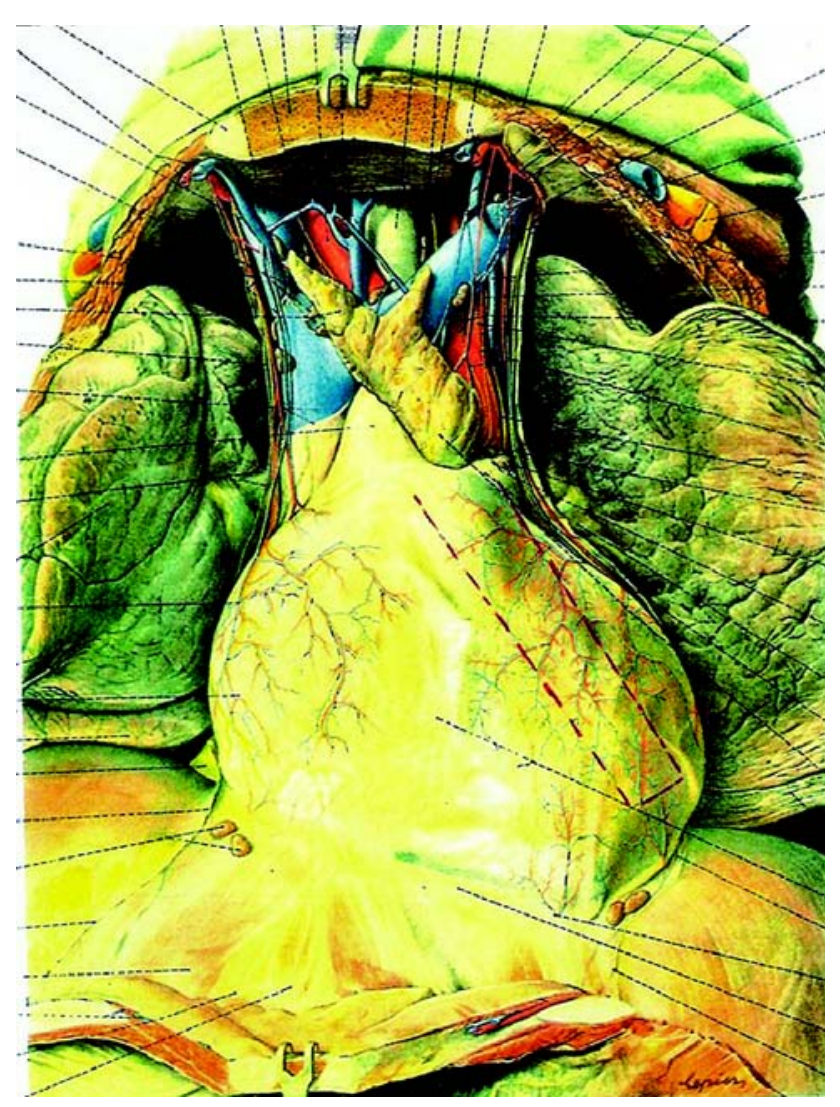

Fig.1 - Abundant arterial branches that vascularize the pericardium, located near to the phrenic nerve. The pericardial flap anatomic orientation has its proximal side larger than the distal side. The incisions of the pericardial flap are made underneath the nutritional arterial trunks in order not to damage them

The visceral pericardial face is vascularized by coronary artery branches.

It is important not to forget that the pericardium is primarily, a mesothelial tissue and thus, its visceral surface is nourished by oxygen diffusion from the blood that is in direct contact with it. This oxygen diffusion is totally dependent of the existence of a partial oxygen pressure 
tension. This diffusion process only happens in the pericardial serous sac. As is well known, arterial blood has one of the highest levels of partial oxygen pressure tension in the human body [10].

9) The pediculated pericardial flap has a larger width in it proximal portion in order to preserve the greatest arterial blood nourishment.

10) During implantation of the pericardial flap, the proximal suture line into the transverse "T shape" part of the lengthwise aortic incision is made with individual stitches using fine cardiovascular thread. It is necessary to take care to pass these stitches to the side of vascularizing pericardial arterial branches without puncturing or tying them.
11) The rest of the implantation of the flap in the descending thoracic aorta is made by a continuous suture using the same thread. Thus, the pediculated pericardial flap remains vascularized normally and the serous pericardium sac continues in direct contact with the pulsatile aortic arterial blood circulation which has a high partial oxygen pressure tension, capable of maintaining the pericardial flap nourished by the aforementioned oxygen diffusion mechanism.

12) The posterior portion of the end-to-end anastomosis is performed with the same thread using single stitches. It is important to mention that these are not purse-string sutures (Figure 2).

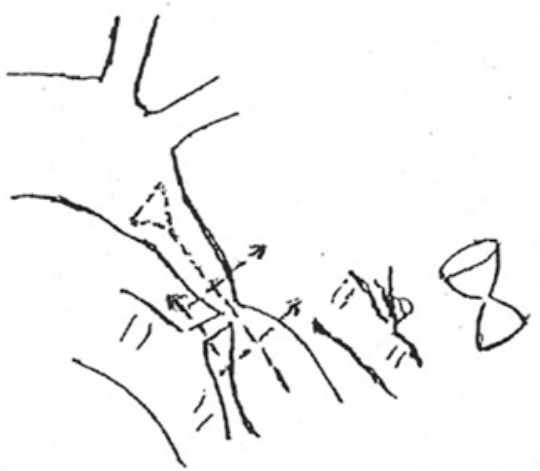

A

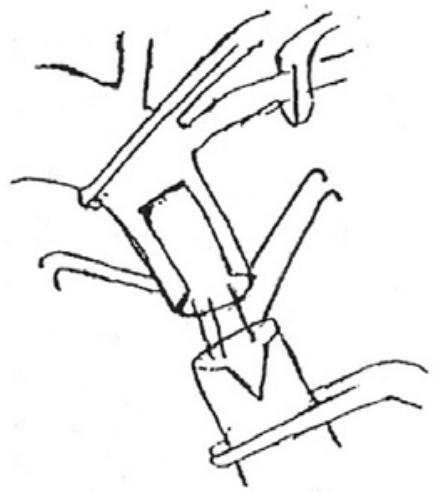

$\mathrm{B}$

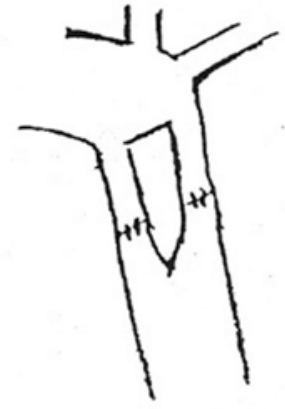

c
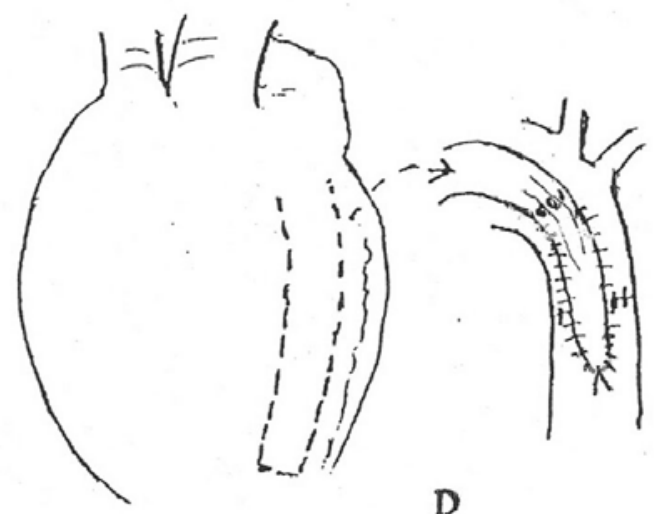

D

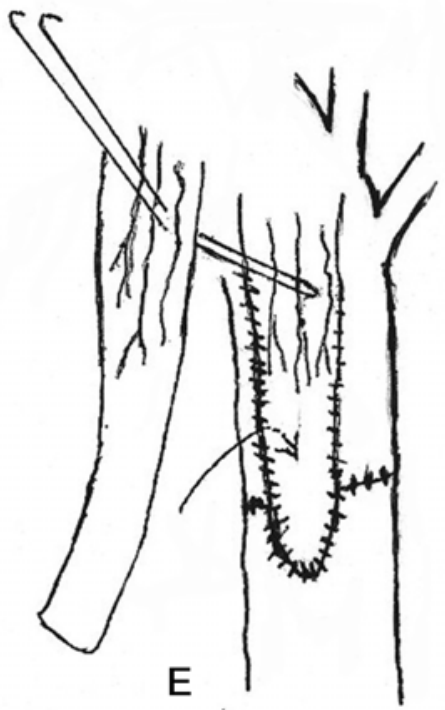

Fig.2 - A step by step diagram of the surgical implantation of the vascularized pericardial flap to the aortic wall; $E$ - A diagram of the surgical technique of a double pericardial vascularized flap being implanted (one over the other) on the aortic wall, preserving the arterial nutrition of both flaps 
The application of this surgical technique is indicated in cases of atresia of the ascending aorta or for luminal interruption of aortic arch. In these lesions, however, the pericardial flap is isolated from an area farther to the right of the pericardial sac in the continuous right phrenic nerve region.

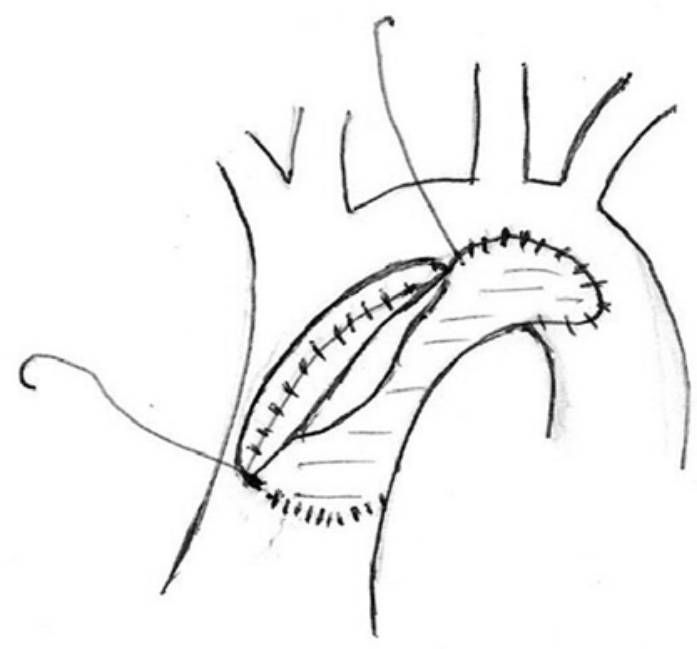

A

Fig. 3 - Surgical implantation of a plastic or a non-autologous biological patch during the Norwood's operation - this patch does not accompany the patient's growth

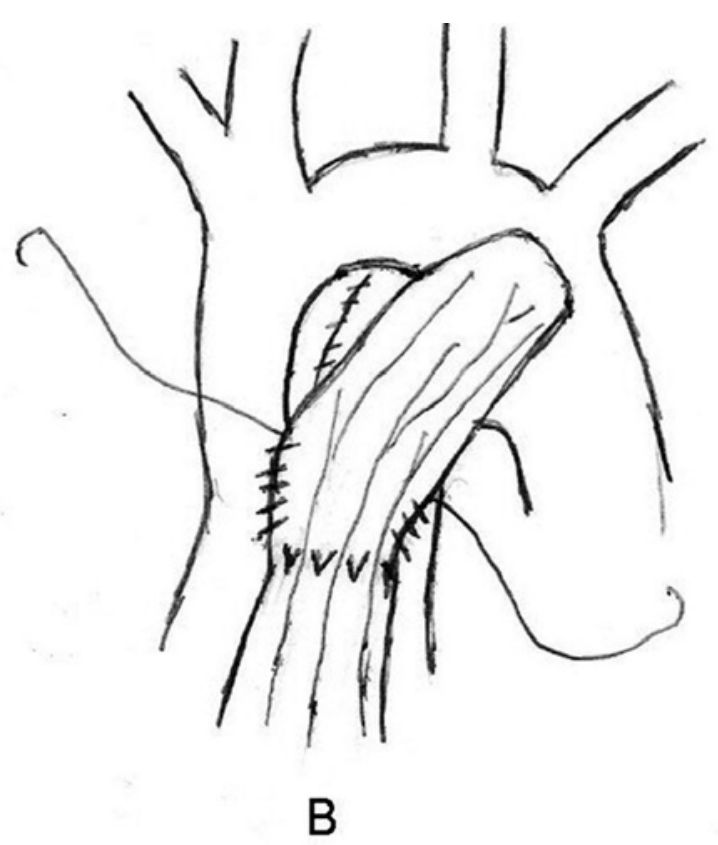

Fig. 4 - surgical implantation, using the same Norwood's operation, of an autologous vascularized pericardial patch which grows as the patient gets older and taller. These patients are, usually, operated on during the neonate period
As many of these patients are operated on at a few days or weeks of life, it is important to apply a type of aortic patch that grows normally accompanying the patient's growth; this occurs with this pediculated vascularized autologous pericardial flap.

During the Norwood operation, at the correction stage of atresia of the ascending aortic, instead of using a plastic or non-autologous biological tissue patch, as often these patients are newborn babies, a pediculated vascularized autologous pericardial flap should be used which grows in width and length (Figures 3 and 4).

In all patients, particularly newborn babies, prostaglandin E1 (PGE1) is prescribed in the pre-operative period in order to maintain the patent ductus arteriosus open and to allow surgical heart correction with the patient in a more stable hemodynamic state.

We try to keep the patient's $\mathrm{pCO}_{2}$ at around $50 \mathrm{mmHg}$ (in hypocapnia) by means of controlled ventilation with reduced ventilatory frequency and with $100 \%$ oxygen inhalation. Hence, we duplicate the sources of cerebral vascular arterial protection in patients with low ejection fractions.

\section{RESULTS}

The two patients ( 8 months and 13 years old) were operated on using this surgical technique 18 years ago and have not suffered from any complication related to the surgery. After surgery, whilst in the operating room, there was no pressure gradient above and below the operated area (the coartectomized area).

Periodic outpatient evaluations have shown normal pulses of the femoral artery and distal branches and normal arterial pulses in the arms. Eighteen years after surgery, there is no arm/leg pressure gradient, which rules out the possibility of postoperative recoarctation.

Both patients have had normal systolic blood pressures during these 18 years and no abnormal cardiovascular symptoms.

Both have grown in a normal manner physically and both participate in normal sporting activities with no physical limitations at all in the postoperative period (Figure 5).

Doppler echocardiograph examinations for both patients have shown normal blood flows and the absence of arterial pressure gradients. Electrocardiographic evaluations were also normal in the postoperative period.

All invasive surgical evaluations have shown normal findings.

Both patients were submitted to cardiac catheterization followed by cine ventriculography and thoracic aortography in the $18^{\text {th }}$ postoperative year, which demonstrated a normal aortic configuration and diameter, particularly at sites above and below the coartectomized area (Figure 6). 
Stress tests, 18 years after surgery gave the following results: effort

a) Adequate tension response to the subjected physical

b) Adequate chronotropic and inotropic responses

c) Absence of signs of myocardial ischemia

A thoracic angiotomographic evaluation of the ascending and descending aortas and aortic arch of both patients showed:

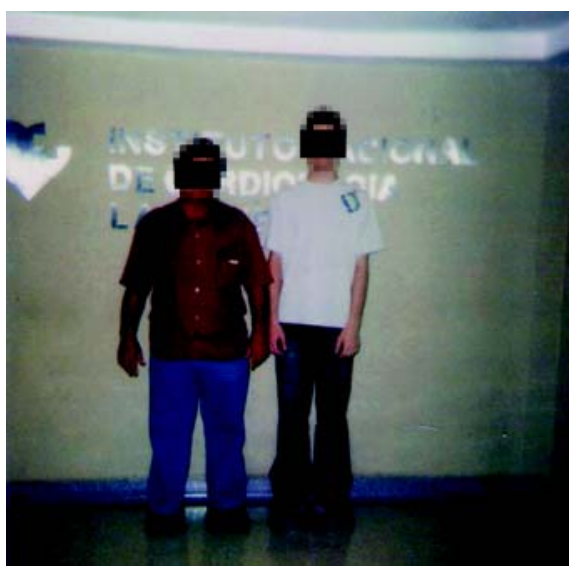

Fig. 5 - Normal patient's growth - he was operated on at 8 months old and later grew taller than his father

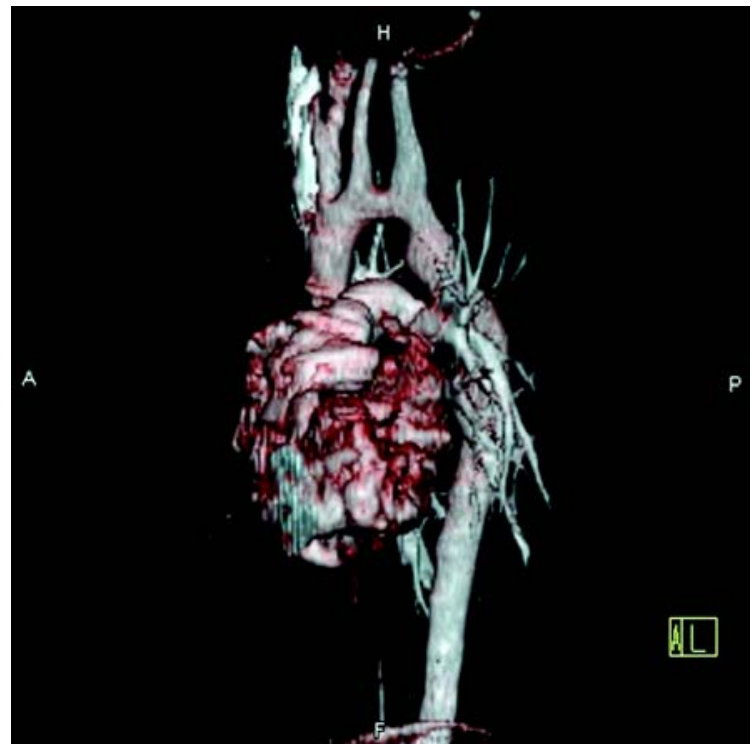

Fig. 7 - Thoracic angiotomography of a patient operated 18 years previously, at the age of 13 years. There is perfect growth of the coarctectomized area without any sign whatsoever of postoperative re-coarctation a) A normal aortic configuration and diameter

b) Normal diameter of the descending thoracic aorta with similar diameters above and below the coartectomized region (Figures 7 and 8).

c) Growth of the pediculated vascularized pericardial flap both in respect to its diameter and its length.

d) The absence of aneurysmatic, degenerative or calcified (atherosclerotic) complications of the pericardial flap.

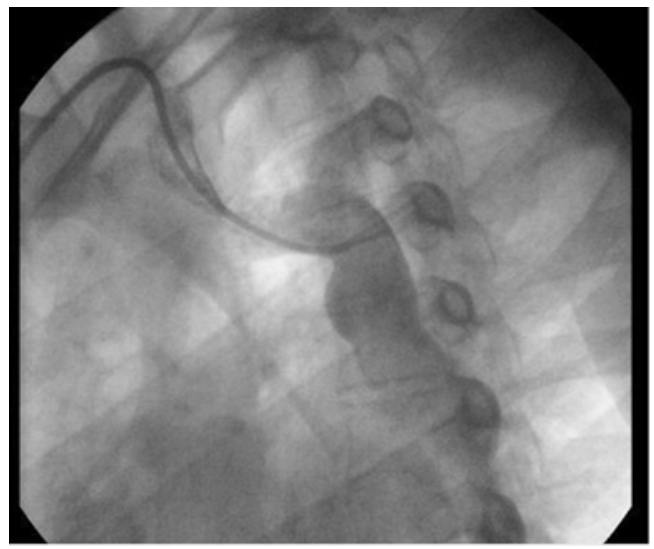

Fig. 6 - Thoracic aortography of a patient operated on at 8 months old. Eighteen years after surgery, the thoracic aortography shows a perfect physical growth of the vascularized pericardial flap and the fact that there is no pressure gradient through the operated area

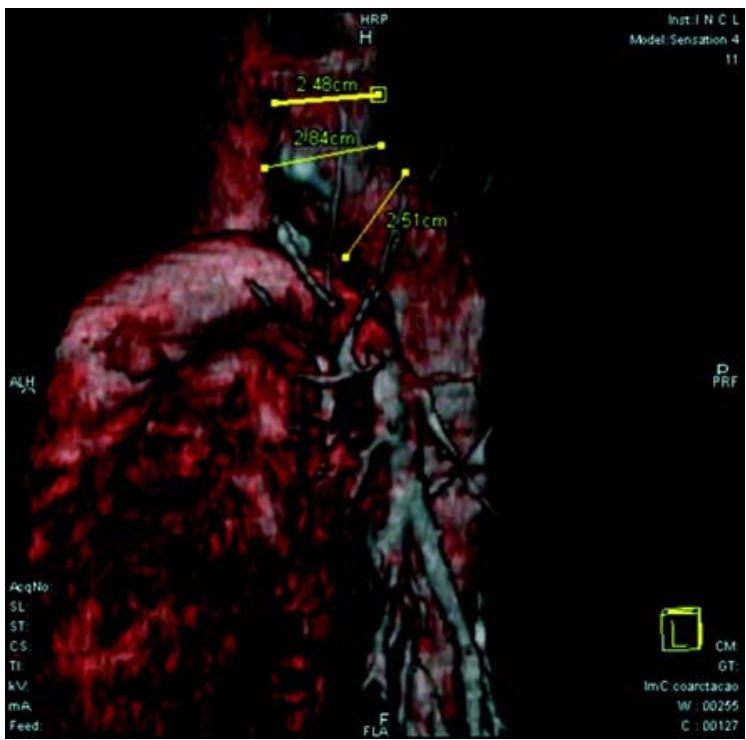

Fig. 8 - Thoracic angiotomography of a patient operated 18 years previously at the age of 8 months showing an excellent surgical result with perfect growth of the coartectomized area 


\section{DISCUSSION}

Although it has been more than sixty years since the first successful correction of aortic coarctation, we still do not have an ideal surgical technique which can be successfully used for all the forms of this congenital aortic disease.

Thus, we have no possibility of surgically treating all patients at different ages, particularly newborn babies, without them suffering from future complications.

The new surgical technique that we are now describing fulfills all the requirements to qualify as an "ideal technique" and has technically surpassed, in results, all other previously reported surgical techniques.

Our surgical technique is based on several basic clinical, surgical and experimental publications as listed below:

- Beck, in 1954 [11] knowing that the pericardium is one of the most vascularized human tissues presented an original surgical technique for myocardial revascularization. This technique basically consisted in surgical abrasion of the internal face of the pericardium and of the external surface of the myocardium (epicardium).

Following this, asbestos powder was uniformly spread over the abraded surfaces between the epicardium and pericardial sac, creating a chemical non-infected pericarditis.

With surgical adhesion of the epicardium to the pericardium, the latter supplies arterial pericardial blood from its normal vascularization to the myocardial mass resulting in surgical myocardial revascularization (Beck operation I and II).

This was considered an excellent clinical cardiologic result at that time.

- Stenseth et al., in 1971, [12] published the surgical implantation of non-pediculated autologous pericardial patches for thoracic aortic enlargement of the ascending portion of the aorta; a technique applied in several patients with a clinical follow up of 15 years, demonstrating excellent results.

The insertion of autologous non-pediculated pericardial patches to the right side of the circulatory system may cause the appearance of aneurysms as is seen at the right ventricle outflow tract [9].

It is well know that the implantation of autologous, nonpediculated, pericardial patches on the arterial side of the circulation gives much better results than on the venous side.

There are several the reasons for this:

- Lam et al. [10] defined the pulsatile arterial strength as a valuable point for keeping the biological tissue whole. As the biological tissue is avascular, it is nourished by the oxygen diffusion process. The pulsatile arterial strength has great importance in this oxygen diffusion process.

Oxygen diffusion is very important to maintain the structural and functional integrity of transplanted biological tissue, such as the pericardium.

Clarke [13] demonstrated that tissues, such as heart valves or pericardium as well as non-pediculated and nonvascularized patches (being mesothelial tissues by origin), are nourished by oxygen diffusion.

Underfried [14] determined that proline hydroxylation (which occurs in contact with arterial blood flow that contains high $\mathrm{pO}_{2}$ tension) is an important step toward the formation of tissue collagen, the most important proteic component of animal connective tissue.

Therefore, the partial oxygen tension on the arterial side and its pulsatile pressure mechanism are fundamental factors making the pericardial patch behavior on the arterial side better than its behavior on the venous circulatory side, which has proved to be very bad.

Bastos [15] in 1984, in an excellent experimental work involving dogs, showed the histological evolution of nonpediculated autologous pericardial patches implanted for partial reconstruction of the thoracic aorta, as described below:

a) It was histologically proven that the high oxygen level of arterial blood was incapable of keeping the transplanted pericardial patch alive (of course, because it was not a pediculated vascularized pericardial patch).

b) The partial oxygen tension from the arterial blood of the aorta (by means of the oxygen diffusion process) was responsible for the vital maintenance of newly formed tissue that occurs and which is rich in fibroblastic and collagen fibers, capable of keeping the cylindrical aortic shape.

c) Importantly, these neotissues are abundant and are responsible to form the new aortic wall, which is four times thicker than the originally implanted pericardium that has served as its mold.

d) No degeneration, fat infiltration or any sign of atherosclerosis were evidenced either in the neotissue, or in the non-pediculated pericardial flap implanted during for a total period of 240 days.

\section{CONCLUSIONS}

It is clear to us that the pediculated autologous vascularized flap, associated with a nourishment source provided by oxygen diffusion is the best form, from technical and surgical points of view, of aortoplasty during correction of aortic coarctation, associated or not to hypoplasia, atresia or luminal interruption of the aortic arch.

It is also clear, that with our pioneering surgical technique, it is possible to operate on patients of any age with this type of lesion, including newborn babies, which is the ideal 
time to perform this surgery. Hence, continuation of high systemic arterial hypertension will be prevented.

Considering the principle of complete resection of the coarcted tissue and the technique of suturing that are utilized with this surgical technique (without purse-string sutures), we believe that it is possible to reduce to zero the incidence of re-coarctation in the postoperative period.

This surgical technique is accomplished using only autologous biological tissue. The pericardium is autoavailable, low cost, easy to handle, easy to model and is not porous. As it is not a rigid tissue, the pericardium will diminish the incidence of aneurism formation at the operative site and has low mechanical hemolysis due to blood flow turbulence.

The described surgical technique had a low mortality rate (so far, zero) and there is no need for extensive anatomic dissection and thus there are few operative lesions involving lymphatic ductus or vagus/recurrent nerves.

Apparently, the hesitancy in applying the autologous pericardial patch for aortic wall repair is related to its bad performance in other areas (the venous circulatory side), as well as, the lack of knowledge of surgeons of its long-term histological behavior as a partial substitute of a limited region of aortic wall.

\section{REFERENCES}

1. Crafoord C, Nylin G. Congenital coarctation of the aorta and its surgical treatment. J Thorac Surg. 1945;14:347-61.

2. Gross RE, Hufnagel CA. Coarctation of the aorta: experimental studies regarding its surgical correction. Engl J Med. 1945;133:287-93.

3. Vosschulte K. Surgical correction of coarctation of the aorta by “isthmuplastic" operation. Thorax. 1961;16:338-45.
4. Waldhausen JA, Nahrwold DL. Repair of coarctation of the aorta with subclavian flap. J Thorac Cardiovasc Surg. 1966;51(4):532-3.

5. Amato JJ, Rheinlander HF, Cleveland RJ. A method of enlargement the distal transverse arch in infants with hypoplasia and coarctation of the aorta. Ann Thorac Surg. 1977;23(3):261-3.

6. Mendonça JT, Carvalho MR, Costa RK, Franco Filho E. Coarctação da aorta: uma nova técnica cirúrgica. Arq Bras Cardiol. 1985;44(3):181-3.

7. Dinkhuysen JJ, Almeida TL, Pinto IM, Souza LCB. Tratamento cirúrgico da coarctação da aorta pela aortoplasia trapezoidal. Arq Bras Cardiol. 2004;82(1):9-17.

8. Tabayashi K, Tanaka Y, Endo M, Sai S, Masuda S, Sadahiro M. Right ventricular outflow reconstruction with nonsutured pedicled autologous pericardium. J Thorac Cardiovasc Surg. 2001;121(6):1203-5.

9. Rosenthal A, Gross RE, Pasternac A. Aneurysms of right ventricular outflow patches. J Thorac Cardiovasc Surg. 1972;63(5):735-40.

10. Lam CR, Aram HH, Munnell ER. An experimental study of aortic valve homografts. Surg Gynecol Obstet. 1952;94(2):129-35.

11. Beck CS. Operations for coronary artery disease. J Int Coll Surg. 1954;21(3:1):314-21.

12. Stenseth JH, Danielson GK. McGoon DC. Pericardial patch enlargement of the aortic outflow tract. J Thorac Cardiovasc Surg. 1971;62(3):442-8.

13. Clarke JA. An X-ray microscopic study of the blood supply to the valves of the human heart. Br Heart J. 1965;27:420-3.

14. Underfried S. Formation of the hydropropoline in collagen. Science. 1966;152:1335.

15. Bastos ES. Restauração parcial da aorta com pericárdio autógeno: estudo experimental em cães [Tese de Doutorado]. Rio de Janeiro:Faculdade de Medicina da Universidade Federal do Rio de Janeiro;1984. 